\title{
Trade between Sweden and Portugal in the Eighteenth Century : Assessing the Reliability of STRO Compared to Swedish and Portuguese Sources
}

\section{Ojala, Jari}

Brill

2018-11-01

Ojala , J , Karvonen , L , Moreira , C \& Eloranta , J A 2018 , Trade between Sweden and Portugal in the Eighteenth Century : Assessing the Reliability of STRO Compared to Swedish and Portuguese Sources . in J W Veluwenkamp \& W Scheltjens (eds), Early Modern Shipping and Trade : Novel Approaches Using Sound Toll Registers Online . Brill's studies in maritime history , vol. 5 , Brill , Leiden . https://doi.org/10.1163/9789004371781_010

http://hdl.handle.net/10138/325742

https://doi.org/10.1163/9789004371781_010

unspecified

acceptedVersion

Downloaded from Helda, University of Helsinki institutional repository.

This is an electronic reprint of the original article.

This reprint may differ from the original in pagination and typographic detail.

Please cite the original version. 


\section{Trade between Sweden and Portugal in the Eighteenth Century: Assessing the Reliability of the Danish Sound Toll Registers by Comparing Them with Swedish and Portuguese Sources ${ }^{1}$}

Jari Ojala, Lauri Karvonen, Maria Cristina Moreira, Jari Eloranta

\section{Introduction}

The scarcity and unreliability of information, but also the measures current prior to the metric system have meant a daunting workload for any economic historian wishing to analyse trade flows in the early modern period. ${ }^{2}$ The recent digitization of the Danish Sound Toll Registers (STR) has opened up uniform and continuous datasets easily available to researchers to study the commercial shipping and commodity flow patterns of early modern Europe in aggregate and in detail. ${ }^{3}$ Because all vessels passing through the Sound have been registered (except in time of war and certain privileged ships), these registers reveal a lot of information about the micro and macro developments in shipping and trade

\footnotetext{
${ }^{1}$ Funding for this project was provided by the Fundação para a Ciência e Tecnologia, FEDER, PTDC 2010 project PTDC/HIS-HIS/118984/2010: Trade Networks of Small and Neutral States before, during, and after the Revolutionary and Napoleonic Conflicts (1750-1850) and by the Academy of Finland's Center of Excellence "History of Society" and project no. 269654.

${ }^{2}$ E.g. Scheltjens, “The Volume,” pp. 74-75.

${ }^{3}$ Sound Toll Registers Online, www.soundtoll.nl. On the Sound Toll Registers see, for example, Gøbel and Flaskager Hansen, "Denmark."
} 
entering and leaving the Baltic Sea. ${ }^{4}$ However, the STR's value as a historical source must be carefully considered. There are several source-critical analyses focusing on the use of Sound Toll Registers ${ }^{5}$ - some of the older ones include Eli F. Heckscher (1942) ${ }^{6}$, J. Dow (1964) ${ }^{7}$, T.M. Devine and S.G. E. Lythe $(1971)^{8}$, and Sven-Erik Åström (1965 and 1988), just to mention a few that have attempted to assess the value of the STR as a source. The Sound Toll data has been compared with, for example, the Rostock Toll Registers ${ }^{10}$, English port books ${ }^{11}$, Dutch notarial archives, the archives of Claes Adriaensz van

\footnotetext{
${ }^{4}$ Ahonen found only few cases within the STR of vessels which entered the Baltic but never returned. The potential reasons include the possibility that the ship was sold or that the ship's name was changed. There also may have been a shipwreck or the vessel may have returned via the Great Belt, or stayed in the Baltic for some reason for a longer period. The use of other alternative shipping lanes, especially via Hamburg in the nineteenth century, also increased during crises. See Ahonen, From Sugar Triangle, pp. 23-24 and 26. Arup has claimed that ships passed Kronborg under the cover of the night or fog, as mentioned in Zins, England and the Baltic, p. 156.

${ }^{5}$ See e.g. the list in Devine, Exploring the Scottish Past, p. 16 and Scheltjens, De invloed.

${ }^{6}$ Heckscher, "Öresundstullräkenskaperna."

${ }^{7}$ Dow, "A Comparative Note."

${ }^{8}$ Devine and Lythe, "The economy of Scotland."

${ }^{9}$ Åström, From Cloth to Iron, vol 2. Åström, From Tar to Timber (Helsinki, 1988).

${ }^{10}$ Huhnhäuser, Rostocks Seehandel.

${ }^{11}$ Åström, From Cloth to Iron, vol 2.
} 
Adrichem ${ }^{12}$ and the Stockholm Maritime Custom Accounts. ${ }^{13}$ These earlier source-critical examinations have focused on analysing either a few individual products or ships, featured a short time period, or have concentrated on the so-called bjemstedt problem. The overall conclusion arising from these previous studies is that the Sound Toll Registers are reliable to a certain extent, even though serious challenges remain.

This article is a continuation of this tradition of source-critical surveys. Our aim is to evaluate the reliability of the cargo and shipping data in the STR during the period 17381800, by comparing it with two equivalent sets of records in Sweden and Portugal; that is, customs accounts from these two countries. By analysing the number of ships and major commodities in this trade, and by testing statistically the information from different datasets we can draw conclusions about the accuracy of the Sound Toll Registers Online as a source for the study trade and shipping in general. This study adds to the previous debates by including two separate sources to evaluate statistically the reliability of the Sound Toll Registers. The aim of this research, however, is neither to disparage nor discourage the use of any of these records, but to offer some prudent advice on how usable, complementary, and comparable these different historical sources are. Thus, this article is primarily a source-critical survey, although it also offers some insights on the bilateral trade between the Northern and Southern peripheries of Europe during the eighteenth century.

Even though the availability of a large amount of both micro and macro-level data is an obvious strength of the STR, few studies have focused on the reliability of the entire dataset as a source or employed statistical methods when analysing the accuracy of the data.

\footnotetext{
${ }^{12}$ Christensen and Haislund, Dutch trade to the Baltic.

${ }^{13}$ Åström, From Cloth to Iron, vol 2.
} 
Because trade in the early modern period mainly involved bulk cargoes, the STR Online provides a great source to analyse this type of trade. Here we focus on comparing all bulk trade between Sweden and Portugal from 1738 to 1800 carried by Swedish ships.Due to the Swedish Navigation Act valid at the time, it was practically not possible - or profitable - for foreign ships to carry cargoes to and from Sweden so that almost 90 per cent of the goods traded between Portugal and Sweden were carried by Swedish ships (Table 1) As we compare the data from the Sound Toll Registers with two other datasets, namely the Swedish Board of Trade Statistics (SBT) and the Portuguese General Balance of Trade (PBT), we will also be able to reassess the similarity of the Swedish and Portuguese customs records. We argue that the information provided by the Sound Toll Registers and the documentation compiled by the Swedish and Portuguese authorities on the trade volumes match quite well and that, therefore, all three sources are fairly accurate.

We shall first analyse briefly the overall patterns and importance of trade and shipping between Portugal and Sweden, subsequently compare the STR with the Swedish and Portuguese datasets and finally draw some general conclusions.

\section{Swedish-Portuguese Trade}

In the eighteenth century, economic relations between Sweden and Portugal were extensive. In Southern Europe and the Mediterranean area Portugal was the most important trading partner for Sweden; the oldest Swedish consulate (founded in 1641) was located in Lisbon. ${ }^{14}$ During the eighteenth century, Portugal was the most important salt

\footnotetext{
${ }^{14}$ On Swedish-Portuguese trade, see especially Leos Müller, Consuls. See also Müller "Swedish-Portuguese trade". Also, Lindberg “An 18th Century Swedish Perspective.
} 
exporter to Sweden. ${ }^{15}$ In the mid-1750s, for example, a quarter of Setubal's salt went directly to Sweden. For Sweden it was the salt, and for Portugal it was the iron imported from Sweden that were considered as strategic products. In this bilateral trade some other products were also important in certain periods. In the 1720 s, for example, over 50 per cent of Swedish export of boards went to Portugal. During the seventeenth century, the Dutch shipmasters carried the salt imports of Sweden, yet because the key aim in Swedish mercantilist policy was to reduce foreign shipping, Sweden managed to expand its own salt shipping from Portugal after the passing of the Navigation Act in 1724. The Dutch were practically pushed out of this trade between Sweden and Portugal. Throughout the eighteenth century, Sweden also managed to successfully secure its shipping interests in the Mediterranean by making treaties, paying tributes, and maintaining political connections with the Corsair States of Northern Africa.

$<$ FIGURE 1 ROUGHLY HERE $>$

Swedish shipping between Sweden and Portugal continued to grow during the eighteenth century. This trade was, however, disrupted by the Great Northern War (1700-1721), especially when Danish privateers threatened the Swedish vessels. The Swedish consuls reported that in the late seventeenth century some 20 Swedish ships visited Portuguese ports annually. ${ }^{16}$ A century later, the Swedish consuls in Setubal reported large numbers of Swedish ships entering and leaving the town: 133 ships in 1800, 91 ships in 1801, and altogether 94 Swedish ships in $1803 .{ }^{17}$ The information provided by the consular reports

${ }^{15}$ On the Swedish salt trade, see especially Carlén, Staten.

${ }^{16}$ Ekegård, Studier, pp. 70-71.

${ }^{17}$ Swedish National Archives, Board of Trade, Consular reports, Setubal 1800, 1801, and 1803, fol. 422, 426. 
confirms the information from the STR on the overall growth trend in shipping between these two countries. However, the number of Swedish ships calling at Portuguese ports was clearly higher in the consular reports than what was reported at the Danish Sound. This is explained by the fact that Swedish ships were used to carry cargoes between Western and Southern European ports and the fact that this practice grew in importance during the French Revolutionary and Napoleonic wars as the Swedes were able to benefit from their neutrality. Carlson argues that as much as half of the Swedish tonnage in the Mediterranean area during the eighteenth century was used in this type of tramp shipping.Moreover, a sizable number of Swedish ships arrived in Portuguese ports from various other European ports in ballast to load a cargo of salt before returning to the Baltic. $^{18}$

The Sound Toll Records illustrate the Swedish-Portuguese trade patterns quite clearly. First, the ships that carried the commodities between these two countries were mainly Swedish (including those from Finland and the Swedish dominions), with a share of about 90 per cent. Portuguese ships and other nationalities played only a minor part in carrying the total commodity trade between these countries (see Table 1) Second, the holds were almost entirely filled, both in terms of volume and value, with only a few bulk commodities: iron from Sweden and salt from Portugal. Circa two-thirds of the volume of Swedish exports consisted of iron. The Portuguese exports were even more concentrated;

${ }^{18}$ Carlson, "Sveriges handel och sjöfart," pp. 14-15 and 20. See also Ojala, Tehokasta, pp. 144-156. 
in the Sound Toll Registers, salt accounted for 99.1 per cent of the tonnage. The remaining 0.9 per cent was consisted of wine, fruits, sugar, and various luxury items (Table 2). ${ }^{19}$

<TABLES 1 AND 2 ROUGHLY HERE>

\section{Comparability of the data}

In order to evaluate the quality of the STR, we have compared it to similar datasets. Our focus is on the bulk cargoes. The amounts of the most important product groups are easy to compare. The data aggregation enable us to evaluate the differences in volumes found in different sources and whether these differences were systematic or not. The Swedish Board of Trade data (SBT) and the Portuguese General Balance of Trade (PBT) were based on information from customs houses located in different ports. The Swedish data was originally organised and grouped according to product category and then summarised in tables that can be found in the annual reports from the Swedish National Archive. ${ }^{20}$ The

\footnotetext{
${ }^{19}$ In the Swedish Board of Trade tables (Swedish National Archives (Stockholm), Annual reports of foreign trade and shipping), published since 1738, the cargoes from Portugal to Sweden appear to be more diverse. However, the share of salt of the entire cargo volume was substantial.

${ }^{20}$ Riksarkivet, Stockholm, Kommerskollegiums arkiv, Berättelser om utrikeshandel och sjöfart 1738-1805. Serie 1, 2 and 5. See also Vallerö, Svensk handels- och sjöfartsstatistik and Historisk statistik för Sverige.
} 
Portuguese source used in this study is Portugal's General Balance of Trade with Foreign Nations and Portuguese Colonies. ${ }^{21}$

In order to analyse the reliability of STR, we compiled a database covering the years 17381800. This STR-based database included 16,450 product observations, while the database based on the Swedish data (SBT) included 4,911 observations. The Portuguese data (PBT) covered the last decades of the research period and contained 325 product entries. The first step in the comparison of the data samples was to collect, organise, sort, aggregate, and group all the import and export data. The STR export products from Sweden to Portugal were divided into six groups (iron, steel, copper, timber, tar and pitch, and miscellaneous), and the exports from Portugal to Sweden were sorted into five product groups (salt, wine, sugar, fruits, and miscellaneous).

The main grouping principle for cargoes was that the datasets should be as equal and, hence, as comparable as possible. Luckily both the STR and SBT records remained

${ }^{21}$ The balances of trade for each year are in different archives: Biblioteca e Arquivo Histórico de Obras Públicas (Lisbon, Portugal), Balança Geral do Comércio do Reino de Portugal com os seus Dominios e Nações Estrangeiras [Portugal's General Balance of Trade with Portuguese Colonies and Foreign Nations], for the years 1776 and 1777; Alfabeto Das Importaçoens e exportaçoens do Reyno de Portugal com as Naçoens Estrangeiras [Alphabetical list of Portuguese Imports and Exports with Foreign Nations], 1789; Fundação Biblioteca Nacional (Rio de Janeiro, Brasil), Balança Geral do Commercio do Reyno de Portugal com as Naçoens Estrangeiras [Portugal's General Balance of Trade with Foreign Nations], for the years 1783, 1787 and 1798; Instituto Nacional de Estatística (Lisbon, Portugal), Balança Geral do Commercio do Reyno de Portugal com as Nações Estrangeiras [Portugal's General Balance of Trade with Foreign Nations], 1796-1797 and 1799-1800. 
unchanged during the research period. The Portuguese foreign trade datasets were published since $1776^{22}$ with several years missing before 1796 , so that a comprehensive comparison was feasible only for the last ten years of the eighteenth century.

The main concern in the comparisons involves the measures used in the original sources. In the STR, the measures (barrels, lasts [etc.) and customs duties were given for every single product throughout the eighteenth century. Only in less than one per cent of the cases the value of the cargo was reported as well. In the Swedish Board of Trade records, the amounts of all major products were reported using volume measures, while the values were also included. Sometimes, especially in the case of less frequently traded commodities and luxury products, only the value of the commodity was reported.

The STR duties involved specific rates for each commodity. These rates did not change during the period observed. In this study they were used as a starting point in this study for the comparison of the STR with the Portuguese data. However, when using the STR duties rates as estimates for the value and even the volume of trade one has to be especially careful as there was a plethora of rules and regulations for any given period of time to determine how these duties were collected. It is important to notice, for example, that ships might have been from privileged or non-privileged countries. Vessels belonging to the latter

22 The balances of trade for the years 1775,1780 , and 1790 were compiled, as is stated by Adrien Balbi (1822: 401), Essai statistique sur le Royaume de Portugal et d'Algarve, comparé aux autres états de l'Europe, et suivi d'un coup d'oeil sur l'état actuel des sciences, des lettres et des beaux-arts parmi les portugais des deux hemispheres: "Ayant entre les mains (...) les bilans du commerce du Portugal des annés 1775, 1880, 1790 et ceux de 1796 a 1820 si savamment rédigés par M. le chevalier Mauricio José Teixeira de Moraes (...)". However, they do not currently exist in the archives. 
group had to pay somewhat higher duties than others for certain goods. ${ }^{23}$ Even though the differences in paid customs duties were not extensive between various countries and do not, for instance, seem to have affected the sample in this research, this has to be recognised when working with the STR.

Portugal's General Balance of Trade data that was used as a source in this study does not provide commodity volumes but commodity values. Imports were registered as c.i.f. (cost, insurance and freight) and exports as f.o.b. (free on board). The major concern involves the average prices as noted in the Balance of Trade documents in 1796:

"The knowledge about the quantity and quality of the genres by Entrance or Exit was extracted from the Book of Shipments, Relations of customs all around the kingdom and fiscal documentation of this city. For the construction of the balance the prices of the first cost from the port of origin were examined, to the exports will be added the commissions and rights of export: to know these prices some traders of the market, in conference with them, and other well thought speculations, the medium prices have been extracted. ${ }^{24}$

These values, though problematic, enable us to perform statistical comparisons on the annual trade between Portugal and Sweden. The comparative analysis of the Sound Toll and the Portuguese data was conducted by comparing the shares of different products in the imports and exports total. It was not possible to carry out this analysis for the entire period due to the sporadic nature of the annual data; we therefore opted to only provide some descriptive quantitative measures to compare the different datasets.

For the comparison between the STR and SBT, we have used some simple statistical tools. We used a paired $t$-test, which can tell us whether the average export or import shares of

\footnotetext{
${ }^{23}$ Ahonen, From Sugar Triangle, p. 25.

${ }^{24}$ Translated from: Instituto Nacional de Estatística (Lisbon, Portugal), Balança Geral do

Comércio do Reyno de Portugal com os seus Dominios [Portugal's General Balance of Trade with Portuguese Colonies] (1796).
} 
certain products in these two sources differed from each other statistically and if differences can be explained by a sample error. Because these two datasets are clearly interdependent (the same ships declared their cargoes in two different places, and the declaration was based on the same sources, namely cargo manifestos) a dependent t-test, which takes into account the linked nature of the datasets, was also conducted. The second method was based on a linear regression analysis, where the Swedish Board of Trade data was chosen as the dependent variable (the variable to be explained) and the STR as the independent variable (explanatory). While this is an imperfect method to exhaustively explore the question, due to the missing variable bias and other concerns including the interdependence of the data, at least it gives us an indication of the correlation. Before that, the datasets were converted into a logarithmic scale, which describes the percentage changes in the trade. The basic assumption in these tests was that the STR data and SBT datasets were equal. This assumption was made even though the STR volumes should be about 20-30 per cent smaller than the SBT volumes as some shipments from Sweden were exported via Gothenburg and other North Sea ports. The importance of the Swedish west coast for Swedish shipping and trade grew during the period, and ships departing from here to Southern Europe did not have to go through the Sound at all. On the other hand, the general trends in the trade should be the same. Other variables were assumed to be constant. Moreover, Vallerö has noted that the Swedish ships that were loaded or unloaded in more than one Swedish port were possibly recorded at every custom house where some form of clearance took place. ${ }^{25}$ Thus the Swedish Board of Trade information may overestimate the import volumes- although in most cases the cargoes were, in fact, unloaded at only one place.

${ }^{25}$ Vallerö, Svensk, handels- och sjöfartsstatistik, p. 137. 


\section{The STR and the Swedish Board of Trade records}

Comparison between the SBT and the STR reveals that the data on bulk products in these two datasets match satisfactorily. Both sources show similar levels and trend developments for all product groups. Interestingly enough, we can find no systematic errors implying that one source would give systematically higher or lower values than the other source for certain bulk products, either. For some individual years, we can trace substantial differences of several hundred percent between the two sources. However, it is hard to tell what caused these gaps.

$<$ FIGURES 2 AND 3 AROUND HERE $>$

Tar exports from Sweden were a good case to study, because all tar exports were shipped through the Sound. This is because tar was produced either in Finland or in the northern parts of Sweden and exported either via Stockholm or directly from these areas to the European markets; thus the above mentioned challenge of exports being transported via Gothenburg does not concern the tar exports. Figure 2 shows a clear correlation between the Swedish Board of Trade data and the Sound Toll Registers. The annual tar trade was on average about 3,000 barrels, and the median difference between the datasets was only 59 barrels, implying that both datasets were painting the same picture and are, thus, quite reliable.

Bar iron and iron sheets dominated Swedish exports both in terms of volume and value. ${ }^{26}$ As Figure 3 shows, the two datasets corresponded also in the case of Swedish iron and other metals export, in a similar vein as the tar exports in Figure 2. There were also various less important, manufactured metal products like nails, cannons, anchors, bolts, and household goods among the exports. The value per ton of these manufactured products

\footnotetext{
${ }^{26}$ Karonen, Pohjoinen suurvalta, pp. 145-148 and 179-182.
} 
was, of course, higher than that of bar iron. Some of these metal goods, like nails, were reported with their values in the SBT, and were, therefore, grouped under miscellaneous products in this study.

\section{<TABLE 3 ROUGHLY HERE $>$}

The t-test, showing if the means of the product shares were similar or not, clearly confirmed the same phenomenon as the figures above (see Table 3): there was no substantial difference in the bulk cargo export volumes from Sweden to Portugal between the STR and SBT datasets (especially columns T-test and probability). In each cargo group the Sound data values were consistently slightly smaller than in the Swedish data. We contend that the STR statistics are precise enough when it comes to the measuring of Swedish bulk export cargoes, presuming that the Swedish manner of filling in freight letters and customs inspections was correct and precise.

Judging from the Swedish exports to Portugal it is likely that the tar figures can be evaluated as the most reliable in the STR and SBT. The volumes of iron, steel, and copper exports, too, seem to have been reported rather similarly in Elsinore and in the Swedish ports. According to this analysis, however, the figures for the timber trade differed substantially between the STR and SBT. This difference may have resulted from the diversity of this product group, and in a related manner, from the rather challenging measurement of the timber cargoes. Numerous timber qualities and products were included in this group and we may assume that the variety of product names in the product group reflects the dissimilarity of the records, for example reporting in terms of numbers of items, tonnage etc. Moreover, the use of a simple linear regression (Ordinary Least Squares, see Appendix 1) reveals that the two sources tracked changes in the iron and tar trade fairly similarly. 
When analysing the Portuguese exports to Sweden the different units used in the STR and the SBT and the ambiguity and diversity of the units mean that the comparison was not as simple to carry out as with the Swedish export products (see Figure 4). We converted all salt shipment volumes to lasts, even though barrels were also used in the Swedish data. ${ }^{27}$ There was a clear correlation between the STR and SBT data on salt imports from Portugal, even though some of the salt was imported via Gothenburg and, thus, did not show up in the Sound Toll figures. This may explain why the trends were similar, yet the SBT data suggest higher salt import volumes than the STR for most of the period. When it comes to wine and fruit imports, a clear systematic difference was apparent. The Portuguese wine industry developed significantly during the eighteenth century, and both the Sound Toll Registers and the Swedish authors have recorded similar wine types, albeit the SBT listed wine qualities a bit more precisely and listed a few French wines as also being imported from Portugal. Because of this, we have chosen to examine only three wines from the SBT: Portuguese, Malaga, and Muscat wines, all of which can also be found in the STR. In practice, the majority of the imports from Portugal constituted "normal" Portuguese wine, supplemented with some more expensive wines. Thus, the general trends and import amounts can be distinguished by comparing the datasets. The various types of wine posed some challenges for the analysis as we had to convert the amounts into litres. The most significant challenge was the conversion of oxehoved (in the STR). As we could not find a precise converter for oxehoved, and only an inaccurate measure of 183-325 litres

\footnotetext{
${ }^{27}$ Note that for single years the SBT data implied that, in addition to 'Portuguese salt', also Luneburger Salt, Collberger Salt, Franskt Salt, and Medelländskt Salt was imported from Portugal. In this comparison only the 'Portugiskt och spanskt salt' imported from Portugal was included.
} 
was available, we used the approximation of 206 litres as a converter. For the Swedish unit amar, there was a more precise converter of 155 litres, which was used in our study. ${ }^{28}$ As fruit was a continuous part of the imports from Portugal, it is interesting that the Danish and Swedish officials used different unit measures. In the STR, the measure for fruits was kiste, meaning a case, while in Sweden the fruit trade was documented in barrels, as well as in terms of value. As we could not know whether the Swedish barrel and the STR case were equivalent or not, an index was used as a basis for the comparison. In all, the STR and SBT data do not track well with each other in the case of wine and fruit. Thus, with these commodities one should be cautious when using the Sound Toll Online database.

$<$ TABLE 4 ROUGHLY HERE $>$

As the probability values seen in Table 4 show, there were obvious differences in the means of the STR and STB data concerning the Portuguese exports to Sweden. The volumes were consistently and significantly larger in the SBT data than in the STR. When it comes to the most important commodity, salt, the difference in the mean STR volume was 77 per cent of the SBT. This is in line with the assumption that the North Sea coast accounted for some 20-30 per cent of Swedish foreign trade. Along the same lines, the wine and sugar trade showed notably lower volumes in the STR than in the SBT.

There were also substantial differences in the fluctuations of the series, not just in the levels. The linear regression model (OLS, see Appendix 2) shows that the coefficients of all the Portuguese export products were smaller than those of the Swedish exports of metals and tar. Nevertheless, even here the $\mathrm{R}^{2}$ values for the salt (0.57), sugar (0.57), and wine (0.42) series were high enough to suggest that the trends in the two sources were indeed rather similar.

\footnotetext{
${ }^{28}$ See, for example, Morell, Om mått- och viktsystemens utveckling.
} 
The STR and Swedish Board of Trade records on the Swedish-Portuguese trade were unanimous when it came to most of the trade in bulk products. However, more differences emerged from the analysis of the less frequently traded products, namely sugar and copper. The fact that there were several years in the STR without any mention of sugar or copper, while the SBT data indicated that this trade took place during these missing years as well, implies a shortcoming in the information in the STR. The discrepancy in the information on timber, wine, and fruit trade could be related to the large number of different product names and units in these product categories. It also supports our assumption that the large product groups were more accurately recorded than the smaller ones. The Swedish exports were more consistently reported in the two datasets than the Portuguese exports; this may indicate that the cargo manifestos were completed out more precisely in Sweden than in Portugal.

\section{The STR and Portuguese Board of Trade records}

When examining the STR and Portuguese General Balance of Trade (PBT) records some notable differences but also clear similarities emerge. We would venture to suggest that some of the differences can be explained by different bookkeeping methods. The method and rationality of this comparison can of course be questioned as the Portuguese records were based on the value of the trade measured in the Portuguese monetary unit, the réis, while the STR shares, measured from customs payments, indicate the trade value only in a very rough manner, since the STR documentation is based on cargo quantities. Therefore, the possible differences between the Portuguese and Danish datasets may be explained by the different ways the customs valued the products. As the exact values cannot be found in the Sound Toll Records, we used the rate of the paid customs duties as the basis for our analysis. The STR custom duties were, roughly, about two per cent of the cargo value, so 
there should have been an approximate correlation between the value of the goods and the customs duties paid at the Sound. Also, the comparison with the values in the consular reports indicates that the STR customs duty is a fairly good, albeit rough, estimate of the cargo values. ${ }^{29}$ In general, similar export and import products can be found in the Portuguese custom records and the Sound Toll Registers.

When comparing the Portuguese and the STR data sets, the national differences in the compilation of these trade records are notable. In Sweden and the Sound the foreign trade of the Dominions of Sweden was always recorded separately from that of Sweden proper. For example, the trade between Swedish Pomerania and Sweden was considered to be foreign trade, whereas in the Portuguese statistics the trade with Sweden included both Swedish and Pomeranian goods. Because of this, we have included the trade flows from Swedish Pomerania (the ports of Barth, Greifswald, Wolgast and Stralsund) in the analysis of the STR data. When comparing STR and SBT these areas were not included in the analysis.

$<$ TABLES 5 AND 6 ROUGHLY HERE $>$

Tables 5 and 6 display a clear difference in the shares of the most important products in the Swedish-Portuguese trade in the Sound Toll Registers on the one hand and in the

${ }^{29}$ There were differences in the cargo valuation at the Sound and in Portugal. The consular reports indicate that the value of timber was higher in Portugal than at the Sound (relative to other commodities inspected here). For instance, a 1729 consular report of the product values in Portugal gives the following shares: 87 per cent iron and steel; 13 per cent timber; 0.34 per cent tar. At the same time, the STR shares (measured from customs duties) are: 91 per cent iron and steel; 8 per cent timber; 0.6 per cent tar. Müller, Consuls, p.98. 
Portuguese customs records on the other. In the Sound Toll Registers the iron and steel cargoes made up most of the value of the commodities carried on the Swedish ships (Table 6) This information is clearly in line with the overall picture of the Swedish export trade at the time. ${ }^{30}$ Likewise, Tables 7 and 8 indicate that salt was the main product in the Swedish imports from Portugal. However, the shares of Portuguese exports to Sweden differ notably in both sources. Salt, for example, played a more pronounced role in the STR data, whereas in the PBT wines and sugar were more significant trade items than in the STR. Nevertheless, the same products can be found in both data sets and, also, closer examination and analysis of the changes in the trade reveal similarities. For example, in both sets of records the timber trade seems to have been at a high level in 1787-89 and 1796, and clearly both statistics reveal a notable grain trade in 1798 .

We suggest three possible reasons why the Portuguese data systematically indicate larger shares of timber and grain, and smaller shares of iron and steel. The first involves the different customs practices. In the Portuguese data, the shares were value-based in local prices, while in the STR the shares are related to the trade volumes. The differences could indicate that the STR customs are not an optimal measure to analyse product values. The second possibility is that, unless otherwise stated in the STR, a large share of the steel and iron cargoes would in most cases have gone to the Netherlands or Britain, while timber cargoes would have reached Portugal as noted in the Sound material. Because there is no evidence of this in the existing literature, this explanation seems tenuous at best. The third option is that in the Portuguese data only Swedish vessels would have been registered, and not the foreign vessels also participating in this bilateral trade. This is not likely, because almost all ships sailing from Sweden to Portugal were Swedish - which was supported by

\footnotetext{
${ }^{30}$ Heckscher, Sveriges ekonomiska historia. See also Åström, From Tar to Timber.
} 
the contemporary Swedish mercantilist policies - though the Swedish navigation act was not as firm for Swedish export trade as it was for import trade. The same reasons might also explain the differences in the share of salt, wine, and sugar imports from Portugal to Sweden.

<TABLES 7 AND 8 ROUGHLY HERE $>$

\section{Conclusion}

The Sound Toll Registers are often described as a unique source with obvious potential for researchers to study the maritime history and trade between the Baltic and Western Europe. ${ }^{31}$ Our comparison firmly supports the argument by Ahonen that the Sound Toll Registers (STR) are an effective barometer of transactions in Northern European EastWest trade. ${ }^{32}$ The STR can also be used to study early modern trade in detail, at the level of an individual vessel, although this approach calls for a measure of caution. When it comes to less traded goods, our research also indicates that there is an asymmetry in the STR data, as the custom registers did not tell the whole story at the level of minute details. In microlevel research, regarding individual ships or specific products, the STR cargoes have to be viewed with caution, and it is strongly recommended to use complementary shipping documents as well. ${ }^{33}$

${ }^{31}$ See for example Gøbel, “The Sound Toll Registers Online Project,” p. 305 and Rich \& Wilson, Economic Organization, p. 226.

${ }^{32}$ Ahonen, From Sugar Triangle, pp. 23-24.

${ }^{33}$ E.g. Gøbel, “The Sound Toll Registers Online Project.” 
Our analysis suggests that harsh criticism of the STR should be disregarded; the registers do provide quite accurate information on trade. ${ }^{34}$ Although the Sound Toll Registers Online provide us with a good overall picture of the trade between Baltic and the rest of Europe - and even to a certain extent with the rest of the world - the picture is far from complete. The Danish Sound was just one spot in the complicated and emerging networks of global shipping and trade. Furthermore, the records reveal only those aspects of trade that were compiled in them in the first place. As Gøbel has emphasized, the registers are correct but not complete. ${ }^{35}$ The value of trade is a complicated issue during the early modern period. The market prices were highly volatile, fluctuating often and widely. This problem cannot be resolved using the customs books. ${ }^{36}$ We recognize and are reminded about the problem of product values and thus trade balance, not to mention the constantly changing exchange rates. ${ }^{37}$ Our analysis suggests, however, that by combining the STR trade volumes with national commodity price datasets we can re at least partially solve the challenges of total trade values. We suggest therefore to use the STR together with national trade and shipping records. Digitization and databases have brought the usefulness of the STR to a new level, and the Sound Toll Registers online database will surely facilitate new comparative research.

\footnotetext{
${ }^{34}$ For instance Schreiner claimed that "the figures on goods passing the Sound had little to do with the facts" - Schreiner, Nederland og Norge, p. 9.

${ }^{35}$ Erik Gøbel, “The Sound Toll Registers Online Project,” p. 321.

${ }^{36}$ Ahonen, From Sugar Triangle, pp. 23-24.

${ }^{37}$ Denzel, Handbook.
} 
Appendix 1. Linear regression analysis (Ordinary Least Squares, OLS) of the

Swedish Board of Trade (Swedish National Archives, Annual reports of foreign

trade and shipping) and Danish Sound Toll data (STRO-dataset) for the Swedish

exports to Portugal 1738-1800

The datasets used here were transformed into a logarithmic scale. The STR data was chosen as the dependent variable and the SBT as the independent variable.

\begin{tabular}{|c|c|c|c|c|}
\hline \multicolumn{5}{|c|}{ IRON } \\
\hline & Coefficient & Std. Error & $\mathrm{t}$ & Prob. \\
\hline $\mathrm{C}$ & 3.072167 & 0.647605 & 4.743893 & 0.0000 \\
\hline Beta & 0.699099 & 0.064374 & 10.86001 & 0.0000 \\
\hline $\mathrm{R}^{2}$ & 0.662807 & & & \\
\hline F-statistics & 117.9397 & & & \\
\hline Prob(F-statistics) & 0.00000 & & & \\
\hline \multicolumn{5}{|c|}{ STEEL } \\
\hline & Coefficient & Std. Error & $\mathrm{t}$ & Prob. \\
\hline $\mathrm{C}$ & 1.338109 & 0.452136 & 2.959530 & 0.0044 \\
\hline Beta & 0.816895 & 0.063177 & 12.93033 & 0.0000 \\
\hline \multirow[t]{2}{*}{$\mathrm{R}^{2}$} & 0.735908 & & & \\
\hline & 167.1935 & & & \\
\hline Prob(F-statistics) & 0.00000 & & & \\
\hline \multicolumn{5}{|c|}{ COPPER } \\
\hline & Coefficient & Std. Error & $\mathrm{t}$ & Prob. \\
\hline $\mathrm{C}$ & -0.214731 & 0.454578 & -0.472373 & 0.6397 \\
\hline Beta & 1.040916 & 0.106060 & 9.814417 & 0.0000 \\
\hline $\mathrm{R}^{2}$ & 0.739109 & & & \\
\hline F-statistics & 96.32278 & & & \\
\hline Prob(F-statistics) & 0.00000 & & & \\
\hline \multicolumn{5}{|c|}{ TIMBER } \\
\hline & Coefficient & Std. Error & $\mathrm{t}$ & Prob. \\
\hline $\mathrm{C}$ & 6.737285 & 1.08964 & 6.181768 & 0.0000 \\
\hline Beta & 0.456182 & 0.090707 & 5.029185 & 0.0000 \\
\hline
\end{tabular}




\begin{tabular}{lllll}
\cline { 2 - 4 } $\mathrm{R}^{2}$ & 0.296540 & & \\
\hline \hline F-statistics & 25.29270 & & \\
\hline Prob(F-statistics) & 0.000005 & & \\
\hline \multicolumn{5}{c}{ TAR \& PITCH } \\
\hline \hline Coefficient & Std. Error & $\mathrm{t}$ & Prob. \\
\hline \hline C & 0.810598 & 0.580360 & 1.396716 & 0.1676 \\
\hline Beta & 0.888354 & 0.075755 & 11.72669 & 0.0000 \\
\hline $\mathrm{R}^{2}$ & 0.696226 & & & \\
\hline F-statistics & 137.5154 & & & \\
\hline Prob(F-statistics) & 0.00000 & & & \\
\hline
\end{tabular}

Appendix 2. Linear regression analysis (Ordinary Least Squares, OLS) of the Swedish Board of Trade (Swedish National Archives, Annual reports of foreign trade and shipping) and Danish Sound Toll data (STRO-dataset) for the Portuguese exports to Sweden 17381800

\begin{tabular}{|c|c|c|c|c|}
\hline \multicolumn{5}{|c|}{ SALT } \\
\hline & Coefficient & $\begin{array}{l}\text { Std. } \\
\text { Error }\end{array}$ & $\mathrm{t}$ & Prob. \\
\hline $\mathrm{C}$ & 0.587000 & 0.876916 & 0.669391 & 0.5059 \\
\hline Beta & 0.891258 & 0.102527 & 8.692908 & 0.0000 \\
\hline $\mathrm{R}^{2}$ & 0.565760 & & & \\
\hline F-statistics & 75.56665 & & & \\
\hline $\begin{array}{l}\text { Prob(F- } \\
\text { statistics) }\end{array}$ & 0.0000 & & & \\
\hline \multicolumn{5}{|c|}{ WINE } \\
\hline & Coefficient & $\begin{array}{l}\text { Std. } \\
\text { Error }\end{array}$ & $\mathrm{t}$ & Prob. \\
\hline $\mathrm{C}$ & 0.651717 & 1.364290 & 0.477697 & 0.6340 \\
\hline Beta & 0.851045 & 0.128483 & 6.623785 & 0.0000 \\
\hline \multirow[t]{2}{*}{$\mathrm{R}^{2}$} & 0.422380 & & & \\
\hline & 43.87452 & & & \\
\hline $\begin{array}{l}\text { Prob(F- } \\
\text { statistics) }\end{array}$ & 0.0000 & & & \\
\hline
\end{tabular}




\begin{tabular}{|c|c|c|c|c|}
\hline \multicolumn{5}{|c|}{ SUGAR } \\
\hline & Coefficient & $\begin{array}{l}\text { Std. } \\
\text { Error }\end{array}$ & $\mathrm{t}$ & Prob. \\
\hline $\mathrm{C}$ & -1.445658 & 1.531775 & $\begin{array}{l}- \\
0.943780\end{array}$ & 0.3516 \\
\hline Beta & 1.034343 & 0.149445 & 6.921220 & 0.0000 \\
\hline $\mathrm{R}^{2}$ & 0.570935 & & & \\
\hline F-statistics & 47.90328 & & & \\
\hline $\begin{array}{l}\text { Prob(F- } \\
\text { statistics) }\end{array}$ & 0.0000 & & & \\
\hline \multicolumn{5}{|c|}{ FRUITS } \\
\hline & Coefficient & $\begin{array}{l}\text { Std. } \\
\text { Error }\end{array}$ & $\mathrm{t}$ & Prob. \\
\hline $\mathrm{C}$ & 1.101890 & 0.793127 & 1.389298 & 0.1699 \\
\hline Beta & 0.922349 & 0.151560 & 6.085714 & 0.0000 \\
\hline $\mathrm{R}^{2}$ & 0.381672 & & & \\
\hline F-statistics & 37.03591 & & & \\
\hline $\begin{array}{l}\text { Prob(F- } \\
\text { statistics) }\end{array}$ & 0.0000 & & & \\
\hline
\end{tabular}




\section{FIGURES AND TABLES}

Figure 1. Number of Swedish Ships Sailing to and from Portugal, 1686-1815 (Left Axis), and Per Cent Share of This Shipping from the Total Swedish Shipping through the Danish Sound (Right Axis), Five-year Moving Averages

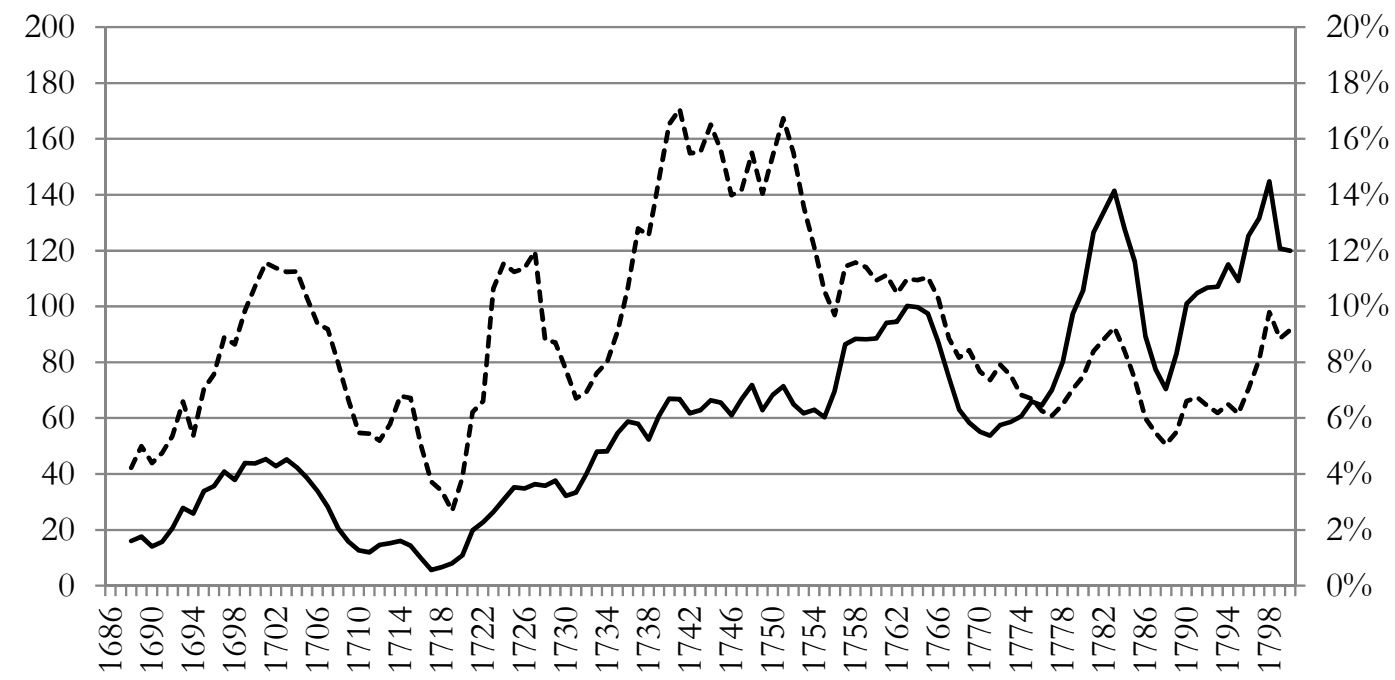

$\longrightarrow \mathrm{N} \quad----$ Share $\%$

Source: Sound Toll Registers Online (STRO)

Note: The figure includes all ship traffic from Sweden proper to Portugal. It does not include the shipping to and from ports of the Baltic Dominions (e.g. Stralsund, Riga and Narva).

Table 1. Nationality of the ships sailing from Sweden to Portugal via the Danish Sound, $1700-1800$

\begin{tabular}{lcc}
\hline Shipmaster's Home Country & $\mathrm{N}$ & $\%$ \\
\hline Sweden (incl. Finland) & 2,891 & 89 \\
Dominions of Sweden & 86 & 3 \\
England & 67 & 2 \\
Netherlands & 62 & 2
\end{tabular}




\begin{tabular}{lcc} 
Prussia/Meckelenburg & 62 & 2 \\
Denmark & 30 & 1 \\
Norway & 13 & 0.4 \\
Portugal & 9 & 0.3 \\
France & 3 & 0.1 \\
Russia & 3 & 0.1 \\
Italy & 2 & 0.1 \\
Spain & 2 & 0.1 \\
United States & 2 & 0.1 \\
Total & 100 \\
\hline Source: Sound
\end{tabular}

Source: Sound Toll Registers Online (STRO)

Table 2. Trade composition measured from tonnage (percentages of total volume) 17381800

\begin{tabular}{lclc}
\hline Swedish Exports to Portugal & $\mathbf{\%}$ & Portuguese Exports to Sweden & $\mathbf{\%}$ \\
\hline Iron & 74.4 & Salt & 99.1 \\
Steel & 4.0 & Wine & 0.21 \\
Timber & 5.0 & Sugar & 0.08 \\
Tar and Pitch & 8.4 & Fruits & 0.003 \\
Copper & 0.3 & .. &.. \\
Miscellaneous & 7.9 & Miscellaneous & 0.61 \\
Average Export Tonnage per Year & 8,508 t. & & 14,171 t. \\
Source: Sound Toll Registers Online (STRO) & &
\end{tabular}

Figure 2. Volume of tar export from Sweden to Portugal, 1738-1800 


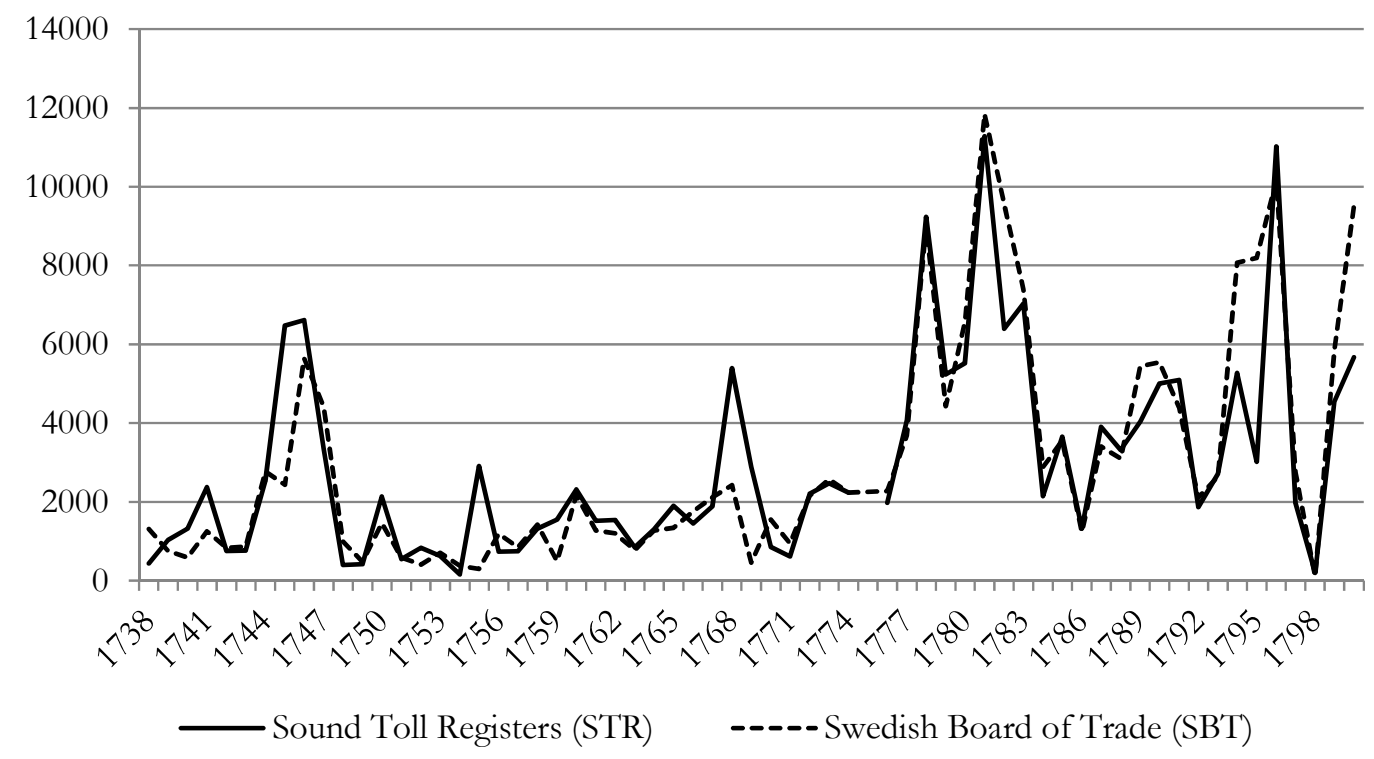

Sources: Sound Toll Registers Online (STRO), Swedish Board of Trade Statistics (SBT)

Figure 3. Volume (in shippounds) of all metal exports (iron, steel, and copper) from Sweden to Portugal, 1738-1800

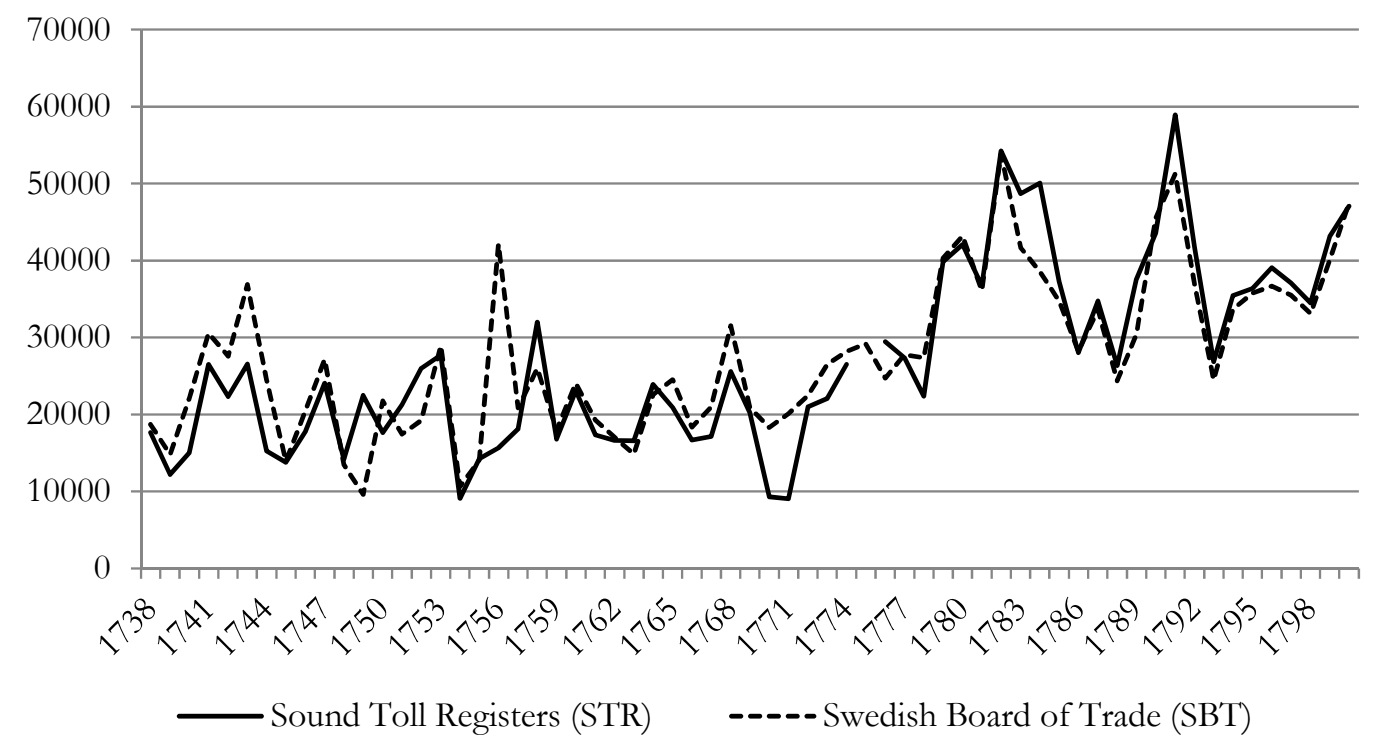

Sources: Sound Toll Registers Online (STRO), Swedish Board of Trade Statistics (SBT) 
Table 3. Comparison of Swedish exports to Portugal: a statistical test on two datasets

\begin{tabular}{|c|c|c|c|c|c|c|c|}
\hline Product Name & Source & Mean & Std. Dev. & $\begin{array}{c}\text { No. of } \\
\text { observations }\end{array}$ & $\mathrm{df}$ & $\begin{array}{l}\text { T-test } \\
\text { value }\end{array}$ & Probability \\
\hline \multirow[t]{2}{*}{ Iron } & STR & 25534.62 & 11299.87 & 62 & 123 & 0.31 & 0.76 \\
\hline & SBT & 26121.62 & 9698.69 & 63 & & & \\
\hline \multirow[t]{2}{*}{ Steel } & STR & 1389.24 & 622.30 & 62 & 123 & 0.30 & 0.76 \\
\hline & SBT & 1422.14 & 593.39 & 63 & & & \\
\hline \multirow[t]{2}{*}{ Copper } & STR & 102.43 & 209.77 & 63 & 120 & 0.34 & 0.74 \\
\hline & SBT & 114.73 & 195.39 & 59 & & & \\
\hline \multirow[t]{2}{*}{ Timber } & STR & 178403.10 & 69384.89 & 62 & 123 & 2.84 & 0.01 \\
\hline & SBT & 214508.70 & 72581.59 & 63 & & & \\
\hline \multirow[t]{2}{*}{ Tar \& Pitch } & STR & 2946.08 & 2531.12 & 62 & 123 & 0.15 & 0.88 \\
\hline & SBT & 3020.34 & 2858.49 & 63 & & & \\
\hline
\end{tabular}

Sources: Sound Toll Registers Online (STRO), Swedish Board of Trade Statistics (SBT)

Figure 4. Volume of salt import from Portugal to Sweden, in lasts, 1738-1800

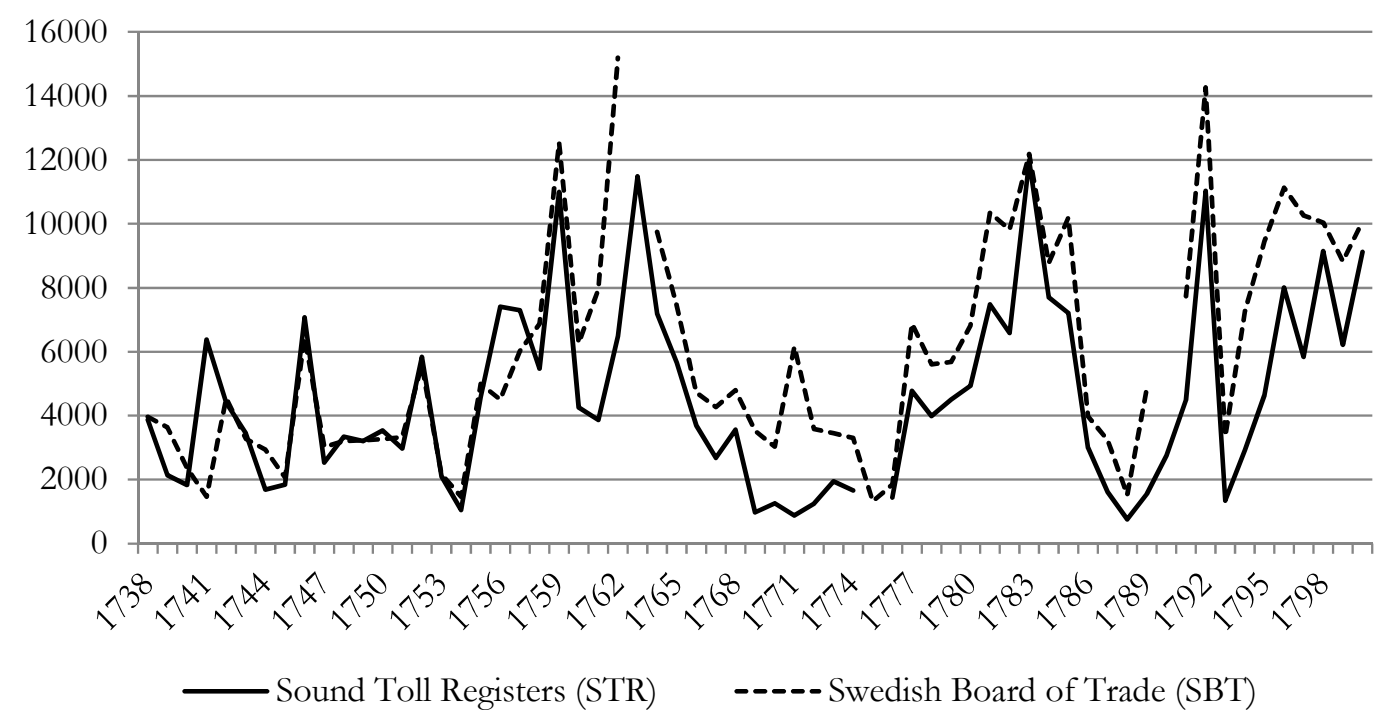


Sources: Sound Toll Registers Online (STRO), Swedish Board of Trade Statistics (SBT)

Table 4. Comparison of Portuguese exports to Sweden: a statistical test on two datasets $1738-1800$

\begin{tabular}{|c|c|c|c|c|c|c|c|}
\hline Product name & Source & Mean & Std. Dev. & $\begin{array}{l}\text { No. of } \\
\text { observations df }\end{array}$ & & $\begin{array}{l}\text { T-test } \\
\text { value }\end{array}$ & Probability \\
\hline \multirow[t]{2}{*}{ Salt } & STR & 4562.65 & 2874.76 & 62 & 121 & 2.36 & 0.02 \\
\hline & SBT & 5898.96 & 3394.79 & 61 & & & \\
\hline \multirow[t]{2}{*}{ Wine } & STR & 29847.98 & 33539.44 & 63 & 124 & 3.89 & 0.00 \\
\hline & SBT & 536818.24 & 35010.66 & 63 & & & \\
\hline \multirow[t]{2}{*}{ Sugar } & STR & 39894.32 & 50556.50 & 38 & 99 & 0.32 & 0.75 \\
\hline & SBT & 63790.32 & 73241.00 & 63 & & & \\
\hline \multirow[t]{2}{*}{ Fruits } & STR & 483.50 & 310.23 & 62 & 123 & -6.69 & 0.00 \\
\hline & SBT & 208.37 & 101.31 & 63 & & & \\
\hline
\end{tabular}

Sources: Sound Toll Registers Online (STRO), Swedish Board of Trade Statistics (SBT).

Table 5. Swedish exports to Portugal according to the Portuguese General Balance of

Trade, percentages of values, 1776-1800

\begin{tabular}{lccccccccc}
\hline & Iron & Steel & Timber & Grain & Tar \& Pitch & Copper & Metals & Others & Total \\
\hline 1776 & 55.0 & 4.9 & 33.0 & & 2.8 & 3.8 & & & 0.5 \\
1777 & 59.1 & 4.1 & 31.1 & & 5.0 & & & 0.7 & 100.0 \\
1783 & 67.3 & 3.4 & 20.3 & 1.5 & 7.3 & 0.1 & & 0.1 & 100.0 \\
1787 & 54.2 & 8.3 & 30.9 & & 5.8 & & & 0.8 & 100.0 \\
178938 & 52.6 & 9.2 & 29.3 & & 5.4 & 0.3 & & 3.3 & 100.0 \\
1796 & 51.4 & 24.9 & 15.7 & & 6.2 & 1.1 & & 0.7 & 100.0 \\
1797 & 50.6 & 10.8 & 11.6 & 14.8 & 4.3 & 1.3 & & 6.6 & 100.0 \\
1798 & 31.3 & 3.0 & 17.4 & 41.0 & 3.1 & & 3.5 & 0.7 & 100.0 \\
1799 & 64.9 & 5.8 & 9.4 & 11.2 & 4.2 & & 3.2 & 1.3 & 100.0 \\
1800 & 67.3 & 4.0 & 10.4 & 5.6 & 2.8 & 3.8 & 5.3 & 0.9 & 100.0 \\
\hline
\end{tabular}

Source: Portuguese General Balance of Trade

Note: In all, the STR and SBT data do not track well in the case of wine. One should

therefore be cautious when using the Sound Toll Online database for this commodity. [.]

\footnotetext{
38 The Balance of Trade for this year does not provide total values for each product and market. Only the overall total of each product and its quantities are available. Therefore, these values reflect mere approximations, as they were calculated with average prices.
} 
Table 6. Swedish exports to Portugal according to the STR, percentages of volumes, 1776-

1800

\begin{tabular}{l|cccccccc} 
& Iron & Steel & Timber & Grain & Tar \& Pitch & Copper & Others & Total \\
\hline 1776 & 80.9 & 10.5 & 6.1 & & 2.1 & & 0.4 & 100 \\
1777 & 76.6 & 10.9 & 4.3 & & 4.2 & 1.8 & 2.3 & 100 \\
1783 & 80.1 & 8.8 & 4.4 & & 4.8 & 0.1 & 1.8 & 100 \\
1787 & 75.1 & 14.3 & 6.9 & & 3.1 & 0.0 & 0.6 & 100 \\
1789 & 72.2 & 13.3 & 7.2 & & 3.0 & 1.1 & 3.3 & 100 \\
1796 & 62.0 & 17.1 & 5.6 & 2.1 & 6.9 & 1.7 & 4.6 & 100 \\
1797 & 64.0 & 17.5 & 2.8 & 9.5 & 1.8 & 1.2 & 3.1 & 100 \\
1798 & 68.1 & 9.1 & 2.5 & 17.1 & 0.2 & 0.1 & 3.0 & 100 \\
1799 & 72.5 & 6.8 & 3.0 & 7.4 & 2.9 & 5.3 & 2.1 & 100 \\
1800 & 70.1 & 15.0 & 3.3 & 4.5 & 3.1 & 2.4 & 1.7 & 100 \\
\hline
\end{tabular}

Source: Sound Toll registers Online (STRO)

Table 7. Portuguese exports to Sweden, according to Portuguese General Balance of Trade, percentages of values, $1776-1800$

\begin{tabular}{|c|c|c|c|c|c|c|c|c|c|c|c|}
\hline & Salt & Wine & Sugar & Fruits & $\begin{array}{c}\text { Spirit } \\
\text { Drink }\end{array}$ & Tissues & Hides & Tobacco & Cotton & Others & Total \\
\hline 1776 & 69.4 & 22.3 & 0.4 & 4.1 & 2.1 & & & & & 1.7 & 100.00 \\
\hline 1777 & 84.4 & 7.8 & & 2.2 & 4.2 & & & & & 1.3 & 100.00 \\
\hline 1783 & 75.7 & 13.9 & 2.4 & 2.6 & 0.2 & & & & 0.1 & 5.1 & 100.00 \\
\hline 1787 & 87.7 & 3.2 & 0.6 & 3.5 & 0.1 & & 1.1 & & & 3.8 & 100.00 \\
\hline $1789^{39}$ & 52.4 & 25.9 & & 8.8 & 0.3 & 8.1 & 2.4 & & & 2.1 & 100.00 \\
\hline 1796 & 71.1 & 3.6 & 18.1 & 3.6 & 1.2 & & 0.1 & & 0.2 & 2.1 & 100.00 \\
\hline 1797 & 69.7 & 4.3 & 14.8 & 6.5 & 1.6 & & 0.8 & & & 2.3 & 100.00 \\
\hline 1798 & 68.2 & 12.0 & 3.3 & 3.3 & 0.2 & & 1.4 & 6.3 & 3.4 & 1.8 & 100.00 \\
\hline 1799 & 58.7 & 20.3 & 9.7 & 8.2 & 0.2 & & 1.1 & & 0.2 & 1.6 & 100.00 \\
\hline 1800 & 57.7 & 11.9 & 3.3 & 14.7 & 0.4 & 0.4 & & & 1.3 & 10.3 & 100.00 \\
\hline
\end{tabular}

Source: Portuguese General Balance of Trade

Table 8. Portuguese exports to Sweden according to the STR, percentages of volume, $1776-1800$

\begin{tabular}{ccccccc} 
& Salt & Wine & Sugar & Fruits & Others & Total \\
\hline 1776 & 85.9 & 11.5 & & 2.6 & & 100.0
\end{tabular}

${ }^{39}$ Please see footnote 38 . 


\begin{tabular}{lcccccc}
1777 & 99.2 & 0.1 & & 0.7 & 0.0 & 100.0 \\
1783 & 98.6 & 0.7 & & 0.2 & 0.5 & 100.0 \\
1787 & 95.3 & 0.6 & & 4.0 & 0.0 & 100.0 \\
1789 & 82.0 & 14.0 & 1.2 & 0.7 & 2.1 & 100.0 \\
1796 & 91.9 & 0.0 & 4.7 & 0.3 & 3.0 & 100.0 \\
1797 & 85.8 & 2.9 & 8.7 & 0.7 & 1.9 & 100.0 \\
1798 & 98.5 & 0.2 & & 0.3 & 1.0 & 100.0 \\
1799 & 91.4 & 1.5 & 4.9 & 1.7 & 0.5 & 100.0 \\
1800 & 99.7 & 0.1 & & 0.2 & 0.0 & 100.0 \\
\hline
\end{tabular}

Source: Sound Toll Registers Online (STRO) 